\title{
Improved Oxygen Release: an Adaptation of Mature Red Cells to Hypoxia
}

\author{
Miles J. Edwards, Miles J. Novy, Carrie-Lou Walters, and \\ JAMES METCALFe \\ From the Heart Research Laboratory and Division of Chest Diseases, \\ Department of Medicine, University of Oregon Medical School, \\ Portland, Oregon 97201
}

A B S T RACT Blood from patients with erythrocytosis secondary to arterial hypoxemia due either to congenital heart disease or to chronic obstructive pulmonary disease was shown to have a decreased affinity for oxygen; the average oxygen pressure required to produce $50 \%$ saturation of hemoglobin with oxygen was $29.8 \mathrm{~mm} \mathrm{Hg}$ (average normal, $26.3 \mathrm{~mm} \mathrm{Hg}$ ). Such a displacement of the blood oxygen equilibrium curve promotes the release of oxygen from blood to the tissues.

Studies were also performed upon blood from a man with complete erythrocyte aplasia who received all of his red cells by transfusion from presumably normal persons. With mild anemia (hematocrit, 28\%), the affinity of his blood for oxygen was slightly diminished (an oxygen pressure of $27.0 \mathrm{~mm} \mathrm{Hg}$ was required to produce $50 \%$ saturation of hemoglobin with oxygen). With

Dr. Miles J. Edwards is an Assistant Professor of Medicine in the Division of Chest Diseases, University of Oregon Medical School. Address requests for reprints to Dr. Miles J. Edwards, Department of Medicine, University of Oregon Medical School, Portland, Oreg. 97201. Dr. Miles J. Novy was a research associate of the National Institute of Child Health and Human Development. His present address is Department of Surgery, Boston University School of Medicine, Boston, Mass. Dr. Carrie-Lou Walters was a research fellow, Oregon Heart Association, now attending Northwestern University Medical School, Chicago, I1l. Dr. James Metcalfe is Professor of Medicine, Oregon Heart Association Chair of Cardiovascular Research.

This work was presented in part at the 21st Annual Meeting of the Western Society for Clinical Research, 2 February 1968, at Carmel, Calif.

Received for publication 14 February 1968 and in revised form 2 May 1968. severe anemia (hematocrit, $13.5 \%$ ), however, his blood had a markedly decreased oxygen affinity (an oxygen pressure of $29.6 \mathrm{~mm} \mathrm{Hg}$ was required to produce $50 \%$ saturation of hemoglobin with oxygen).

We conclude that patients with various conditions characterized by an impairment in the oxygen supply system to tissues respond with a diminished affinity of their blood for oxygen. Although the mechanism which brings about this adaptation is not known, the displacement of the oxygen equilibrium curve is associated with an increase in heme-heme interaction. The decrease in blood oxygen affinity need not occur during erythropoiesis, but may be imposed upon mature circulating red cells.

\section{INTRODUCTION}

Blood from patients with such diverse conditions as arterial hypoxemia due to congenital heart disease (1), high altitude exposure (2-4), and various types of anemia (5-10) has been shown to have a decreased affinity for oxygen. These etiologically and clinically dissimilar conditions have as a common physiological characteristic a decreased oxygen tension and/or concentration in arterial blood. The decrease in blood oxygen affinity can be thought of as a compensatory mechanism which, like erythrocytosis (11), or an increased rate of blood flow, tends to sustain the oxygen tension in blood perfusing tissue capillaries. To test this hypothesis, we measured the oxygen affinity of blood from patients with erythro- 
cytosis secondary to arterial hypoxemia produced by chronic obstructive pulmonary disease, a group not previously studied in this respect. Previous studies on blood from patients with cyanotic congenital heart disease were repeated with new improved techniques.

To clarify the mechanism by which a decrease in the oxygen affinity of blood is brought about in these patients, we calculated the slope of the blood oxygen equilibrium curve using Hill's $n$ (12) as a measure of heme-heme interaction. We also studied blood from a patient with anemia due to complete erythrocyte aplasia. This man received all of his red cells from presumably normal donors by transfusion. We reasoned that if oxygen affinity of blood from this patient was decreased, it would indicate that the mechanism which alters blood oxygen affinity in conditions with an increased danger of tissue hypoxia is capable of acting upon circulating mature red cells.

\section{METHODS}

Patients were considered to have arterial hypoxemia if the oxygen pressure in arterial blood $\left(\mathrm{PaO}_{2}\right)$ at rest was below $60 \mathrm{~mm} \mathrm{Hg}$, or if the oxyhemoglobin saturation in arterial blood $\left(\mathrm{Sa}_{0_{2}}\right)$ was below $85 \%$. Patients were considered to have erythrocytosis if their blood had a hematocrit greater than $55 \%$, a hemoglobin concentration greater than $18 \mathrm{~g} / 100 \mathrm{ml}$, or if the red cell mass was greater than $35 \mathrm{ml} / \mathrm{kg}$ of body weight. Patients were excluded if recent therapy (multiple phlebotomies or discontinuance of oxygen therapy) might have acutely altered their erythrokinetics.

Data from these patients were compared with those obtained from blood of normal volunteers, at rest, and after $20 \mathrm{~min}$ of breathing $10 \%$ oxygen.

We also studied blood from a man (P. L.) of $62 \mathrm{yr}$ who was well until August 1964 when he noted the onset of progressive fatigue, dyspnea, palpitation, and throbbing in the head. At that time, he was found to have a severe anemia and all of his symptoms abated with blood transfusion, only to recur repeatedly as the anemia returned and to be regularly relieved with adequate blood transfusion. A complete absence of red cell precursors was found on repeated bone marrow studies and no reticulocytes were ever seen on multiple peripheral blood examinations. He received testosterone-estradiol, prednisone, and adrenocorticotrophic hormone (ACTH) without beneficial effect. In 1965, a large benign thymoma was resected without remission of his erythrocyte aplasia. His 24-hr urine erythropoietin excretion was consistently found to be extremely high, in the range of $2000 \mathrm{U} / \mathrm{day}$ (normal, 2-8 U). Beginning in 1966, slowly progressive leukopenia and thrombocytopenia were noted. We studied the oxygen-hemoglobin equilibria of blood from this patient on 12 January 1967, and again on 22 August 1967. The patient died suddenly in October 1967. Postmortem findings supported the diagnosis of complete erythrocyte aplasia.

For each study, blood was taken from a peripheral vein without stasis into a syringe containing heparin and sodium fluoride. Oxygen-hemoglobin equilibrium values were determined using the "mixing technique" (13) at a carbon dioxide pressure $\left(\mathrm{PCO}_{2}\right)$ of $40 \mathrm{~mm} \mathrm{Hg}$ and $37^{\circ} \mathrm{C}$. At least two values of blood oxygen pressure and $\mathrm{pH}$, one above and one below $50 \%$ saturation of hemoglobin with oxygen, were determined, and the observed values were corrected for dissolved oxygen (13) and to a standard plasma $\mathrm{pH}$ of 7.40 (14). All studies were completed within $2 \mathrm{hr}$ of venipuncture. Oxygen pressures $\left(\mathrm{Po}_{2}\right)$ at $50 \%$ saturation of hemoglobin with oxygen were determined graphically and will be designated as $\mathrm{P}_{50}$. In some studies, complete oxygen-hemoglobin equilibrium curves were determined and values were calculated for Hill's $n$ (12), which indicates the degree of inflection of the oxygen-hemoglobin equilibrium curve, using the method of least squares. Hill's $n$ may be regarded as an expression of the degree of heme-heme interaction. The magnitude of the Bohr effect was also determined using the "mixing technique" (13) after tonometry of blood

\section{TABLE I}

Oxygen Pressures Found in Blood from Patients with Arterial Hypoxemia and Erythrocytosis after Tonometry and Mixing (13) to Produce the Desired Values of Oxyhemoglobin Saturation

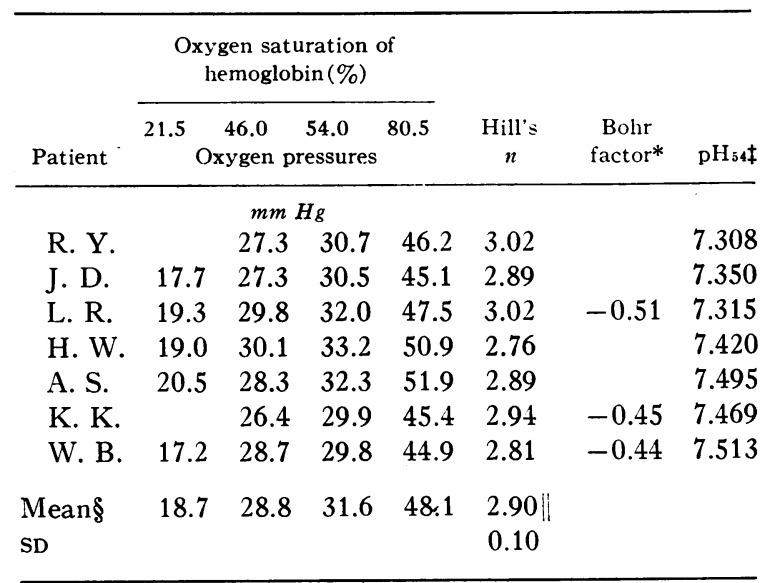

Values have been corrected for dissolved oxvgen and to a plasma pH of 7.40. Calculated values of Hill's $n$ (12), the magnitude of the Bohr effect and the uncorrected plasma $\mathrm{pH}$ (at a carbon dioxide pressure of $40 \mathrm{~mm} \mathrm{Hg}$ and $54 \%$ oxygen saturation of hemoglobin) are also given.

$*$ Bohr factor $=\Delta \log \mathrm{Po}_{2} / \Delta \mathrm{pH}$, at 46 and $54 \%$ saturation. $\ddagger \mathrm{pH}_{54}$, Plasma $\mathrm{pH}$ measured at approximately $54 \%$ oxygen saturation of hemoglobin before correction to a standard plasma $\mathrm{pH}$ of 7.40 .

§ Patients J. D., L. R., H. W., A. S., and W. B.

\| All patients (including R. Y. and K. K.). 
at high and low $\mathrm{PCO}_{2}$, at 46 and $54 \%$ saturation of hemoglobin with oxygen.

\section{RESULTS}

The effect of changes in plasma $\mathrm{pH}$ upon the position of the oxygen-hemoglobin equilibrium curve (Bohr effect) in blood from patients with arterial hypoxemia and secondary erythrocytosis was within the normal range (see Tables I and II). Therefore, the Severinghaus nomogram (14) was used to correct observed values to a plasma $\mathrm{pH}$ of 7.40. When the $\mathrm{Pco}_{2}$ of equilibrating gas was $40 \mathrm{~mm} \mathrm{Hg}$, alkaline values for plasma $\mathrm{pH}$ were found after tonometry of blood from patients with respiratory failure, probably because they had respiratory acidosis and renal retention of bicarbonate. In contrast, the same in vitro $\mathrm{PCO}_{2}(40 \mathrm{~mm}$ $\mathrm{Hg}$ ) produced acid plasma $\mathrm{pH}$ values in blood from patients with cyanotic congenital heart disease, presumably because they had respiratory alkalosis secondary to hyperventilation induced by hypoxemia. The oxygen-hemoglobin equilibrium curves of blood from these two groups of patients came to lie in essentially the same position whether
TABLE II

Oxygen Pressures Found in Blood from Normal Subjects after Tonometry and Mixing (13) to Produce the Desired Values of Oxyhemoglobin Saturation



Values have been corrected for dissolved oxygen and to a plasma pH of 7.40. Calculated values of Hill's $n$ (12) and the magnitude of the Bohr effect are also given.

* Bohr factor, $\Delta \log \mathrm{Po}_{2} / \Delta \mathrm{pH}$, at 46 and $54 \%$ saturation.

TABLE III

Summary of Pertinent Findings in Patients with Erythrocytosis Secondary to Arterial Hypoxemia

\begin{tabular}{|c|c|c|c|c|c|c|c|c|c|c|c|c|c|}
\hline Parent & Age & Sex & Saoz & $\mathrm{PaO}_{2}$ & $\mathrm{PaCO}_{2}$ & $\mathrm{pH}_{\mathrm{a}}$ & \multicolumn{2}{|c|}{ TBV RBC mass } & Het & $\mathrm{Hb}$ & Edema & $\begin{array}{c}\text { Diagnosis and relevent clinical } \\
\text { observations }\end{array}$ & Pso \\
\hline & $y r$ & & $\%$ & \multirow{2}{*}{\multicolumn{2}{|c|}{$m m \mathrm{Hg}$}} & & & & $\%$ & & & & \\
\hline H. C. & 19 & $\mathbf{F}$ & 78.1 & & & & & & & 21.2 & 0 & $\begin{array}{l}\text { Tetralogy of Fallot and ky- } \\
\text { phoscoliosis }\end{array}$ & 30.4 \\
\hline E. H. & 22 & $\mathrm{~F}$ & 79.1 & & & & & & 58 & & $\mathbf{0}$ & Common atrium & 29.5 \\
\hline B. $\mathrm{H}$. & 25 & $\mathbf{F}$ & 78.0 & & & & & & 57 & & $\mathbf{0}$ & $\begin{array}{l}\text { Eisenmenger's syndrome and } \\
\text { kyphoscoliosis }\end{array}$ & 30.5 \\
\hline R. Y. & 28 & $\mathbf{M}$ & 81.3 & & & & & & 71 & & $\mathbf{0}$ & $\begin{array}{l}\text { Patent ductus arteriosus with } \\
\text { reversed shunt }\end{array}$ & 29.0 \\
\hline J. D. & 23 & $\mathbf{M}$ & 81.6 & & & & & & 65 & 21.2 & $\mathbf{0}$ & $\begin{array}{l}\text { Eisenmenger's syndrome and } \\
\text { kyphoscoliosis }\end{array}$ & 28.9 \\
\hline L. R. & 26 & F & 79.0 & & & & & & 65 & 20.0 & $\mathbf{0}$ & $\begin{array}{l}\text { Tricuspid atresia. IASD, and } \\
\text { IVSD }\end{array}$ & 30.9 \\
\hline A. $\mathrm{S}$. & 36 & $\mathbf{M}$ & & 50 & 65 & & 67.9 & 48.0 & 70 & & $2+$ & $\begin{array}{l}\text { Intrinsic asthma and/or } \mathrm{CB} \text {, } \\
\text { obesity }\end{array}$ & 30.3 \\
\hline H. W. & 55 & $\mathbf{M}$ & & 33 & & & & & 63 & & $4+$ & $\begin{array}{l}\text { Severe COPD, myocardial in- } \\
\text { farction, cirrhosis }\end{array}$ & 31.6 \\
\hline C. $\mathrm{s}$. & 65 & $\mathbf{M}$ & & 45 & 55 & 7.40 & 99.1 & 56.0 & 58 & & $4+$ & Severe COPD with heart failure & 29.1 \\
\hline C. $\mathrm{K}$. & 60 & $\mathrm{M}$ & & 41 & 52 & 7.34 & 75.3 & 50.3 & 60 & & $2+$ & $\begin{array}{l}\text { Intrinsic asthma and/or CB, } \\
\text { obesity }\end{array}$ & 28.1 \\
\hline O. W. & 70 & $\mathbf{M}$ & & 53 & 35 & & 85.1 & 50.7 & 59 & & $2+$ & $\begin{array}{l}\text { Unexplained cardiomegaly with } \\
\text { pulmonary edema }\end{array}$ & 29.8 \\
\hline \multirow[t]{2}{*}{ W. B. } & 60 & $\mathbf{M}$ & 、 & 45 & 81 & 7.32 & 80.4 & 57.5 & 71 & & 0 & $\begin{array}{l}\text { Severe obesity, heart failure, } \\
\text { CB }\end{array}$ & 29.3 \\
\hline & & & & & & & & & & & & $\begin{array}{l}\text { Mean } \\
\text { SD }\end{array}$ & $\begin{array}{r}29.8 \\
1.0\end{array}$ \\
\hline
\end{tabular}

SaO2, oxygen saturation of hemoglobin; $\mathrm{PaO}$, arterial blood oxygen pressure; $\mathrm{Paco}$, arterial blood carbon dioxide pressure; $\mathrm{pH}$, arterial blood pH; $\mathrm{TBV}$, total blood volume in $\mathrm{ml} / \mathrm{kg}$ of body weight; $\mathrm{RBC}$ mass, red blood cell mass in ml/ $\mathrm{kg}$ body weight; Hct, hematocrit; Hb, blood hemoglobin concentration $(\mathrm{g} / 100 \mathrm{ml}) ; \mathrm{P}_{50}$, partial pressure of oxygen $(\mathrm{mm} \mathrm{Hg})$ at $50 \%$ saturation of hemoglobin, $37^{\circ} \mathrm{C}$, and plasma $\mathrm{pH}=7.40 ; \mathrm{IVSD}$, interventricular septal defect; IASD, interatrial septal defect; COPD, chronic obstructive pulmonary disease; CB, chronic bronchitis. 


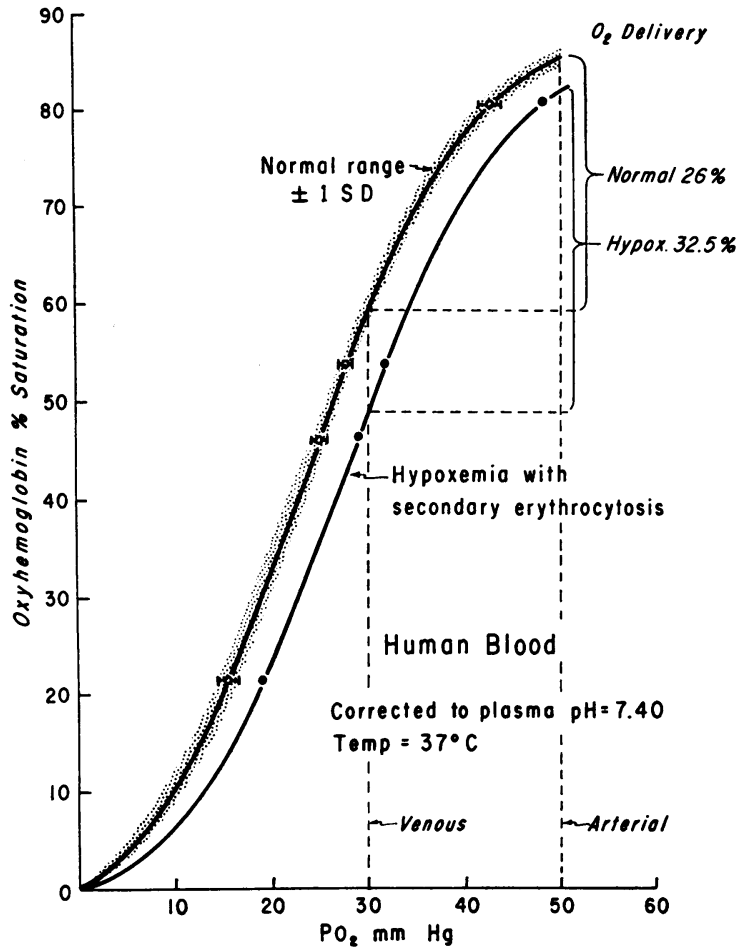

FIGURE 1 Oxygen-hemoglobin equilibrium curves of blood from normal subjects and from patients with hypoxemic erythrocytosis.

the raw data were corrected from more alkaline or more acid plasma $\mathrm{pH}$ values to the standard $\mathrm{pH}$ of 7.40 (see Table I), further evidence that use of the Severinghaus nomogram was valid.

Blood from patients with arterial hypoxemia, due either to respiratory failure or to congenital vascular shunts, differed from normal (Table II) in showing an increased heme-heme interaction (increased Hill's $n) \quad(P<0.01)$ (Table I) and a decreased oxygen affinity (increased $\left.\mathrm{P}_{50}\right)(P<$ 0.01 ) (Table III). A composite oxygen-hemoglobin equilibrium curve for blood from patients with arterial hypoxemia is compared with the curve of blood from normal volunteers in Fig. 1.

Exposure of normal subjects to arterial hypoxemia (produced by breathing $10 \%$ oxygen for $20 \mathrm{~min}$ ) did not change the position of the oxygenhemoglobin equilibrium curve of blood from normal subjects (Table IV).

Values from two studies of blood from P. L. with total erythrocyte aplasia are given in Table V. A graphical presentation of his blood oxygenhemoglobin equilibrium curve in comparison with
TABLE IV

Oxygen Pressures Found after Tonometry and Mixing (13) of Blood to Produce the Desired Values of Oxygen Saturation of Hemoglobin

\begin{tabular}{|c|c|c|c|c|}
\hline \multirow[b]{2}{*}{ Subject } & \multirow{2}{*}{$\begin{array}{c}\text { Oxygen } \\
\text { saturation } \\
\text { of hemo- } \\
\text { globin }\end{array}$} & \multicolumn{3}{|c|}{ Oxygen pressure } \\
\hline & & $\begin{array}{c}\text { Composi } \\
20.9 \% \mathrm{O}_{2}\end{array}$ & $\begin{array}{l}\text { tion of inh } \\
10 \% \mathrm{O}_{2}\end{array}$ & $\begin{array}{l}\text { aled air } \\
\text { Change }\end{array}$ \\
\hline & $\%$ & \multicolumn{3}{|c|}{$m m H_{g}$} \\
\hline C. W. & 21.5 & 16.5 & 16.7 & +0.2 \\
\hline M. E. & 21.5 & 17.3 & 17.2 & -0.1 \\
\hline J. M. & 46.0 & 25.9 & 26.1 & +0.2 \\
\hline C. W. & 54.0 & 27.5 & 27.2 & -0.3 \\
\hline
\end{tabular}

Blood samples were drawn from normal subjects at rest (supine, breathing room air) and again at the end of a 20 min period of breathing $10 \%$ oxygen. Values have been corrected to a plasma $\mathrm{pH}$ of 7.40 .

The duration and magnitude of arterial hypoxemia in each subject during $20 \mathrm{~min}$ of $10 \%$ oxygen inhalation is indicated by the following values of oxygen saturation of hemoglobin (obtained by ear oximetry): C. W.: below $80 \%$ last $8 \mathrm{~min}$, ultimately $74 \%$. M. E.: below $80 \%$ last $10 \mathrm{~min}$. below $70 \%$ last $7 \mathrm{~min}, 60 \%$ last $5 \mathrm{~min}$. J. M.: below $80 \%$ last $15 \mathrm{~min}$, below $70 \%$ last $10 \mathrm{~min}, 66 \%$ last $3 \mathrm{~min}$.

TABLE $\mathrm{V}$

Oxygen Pressures Found after Tonometry and Mixing (13) of Blood to Produce the Desired Values of Oxyhemoglobin Saturation

I. 12 January 1967 , hematocrit $=28 \%$ c

Oxygen saturation of hemoglobin, $\sigma_{\%}$

$\begin{array}{llll}21.6 & 46.7 & 55.2 & 80.5\end{array}$

Oxygen pressures, $\mathrm{mm} \mathrm{Hg}$

$\begin{array}{llll}15.8 & 26.1 & 28.9 & 42.2 \\ 15.0 & 25.7 & 28.5 & 42.7 \\ 15.4 & 25.9 & 28.7 & 42.5\end{array}$

$\begin{array}{lllll}\text { Mean } & 15.4 & 25.9 & 28.7 & 42.5\end{array}$

II. 22 August 1967 , hematocrit $=13.5 \%$

Oxygen saturation of hemoglobin, $\%$

$\begin{array}{llll}23.2 & 49.1 & 57.3 & 82.3\end{array}$

Oxygen pressure, $\mathrm{mm} \mathrm{Hg}$

$\begin{array}{rrrrr}19.6 & 28.9 & 32.3 & 47.1 & 3.11 \\ 19.1 & 29.6 & 32.5 & 47.7 & 2.98 \\ 19.2 & 29.5 & 32.6 & 47.1 & 3.04 \\ 19.3 & 29.3 & 32.5 & 47.3 & 3.04 \\ 0.2 & 0.4 & 0.2 & 0.3 & 0.07\end{array}$

Blood samples were drawn from P. L. on two different dates and at two different hematocrit levels. Values have been corrected for dissolved oxygen and to a plasma $\mathrm{pH}$ of 7.40 . Calculated values of Hill's $n$ (12) are also given. 


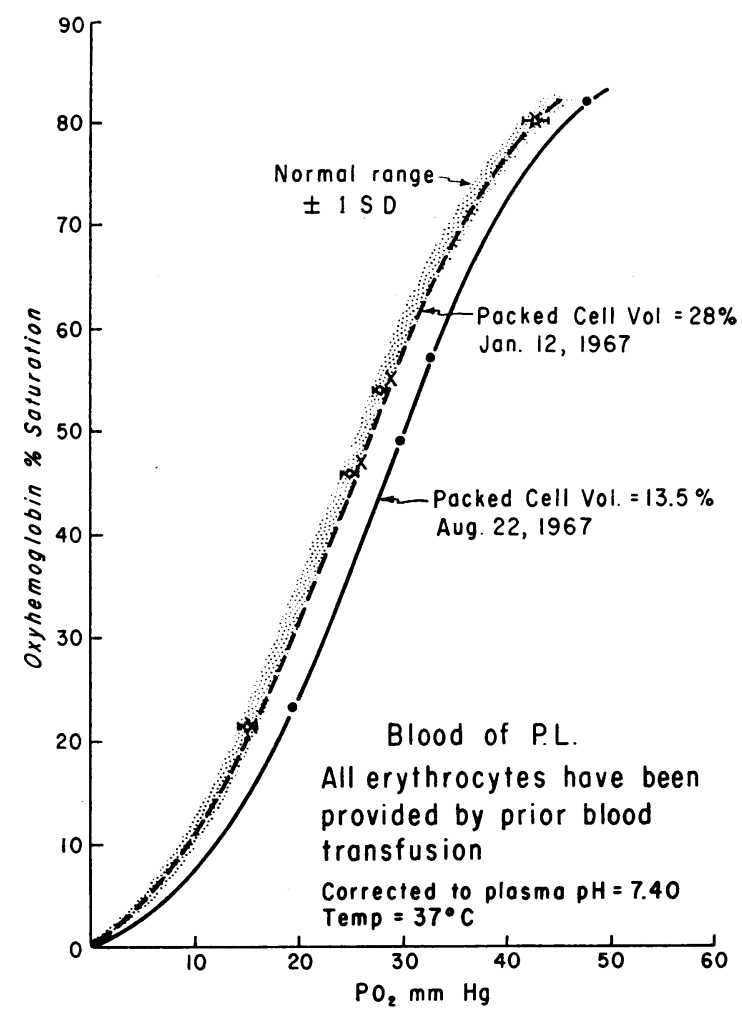

FIGURE 2 Oxygen-hemoglobin equilibrium curves of blood taken from P. L. at hematocrit levels of 28 and $13.5 \%$, respectively, compared with normal values (stippled area).

that of normal blood is shown in Fig. 2. On January 12 , when his hematocrit was $28 \%$ (his most recent transfusion had been given 6 days earlier), the oxygen affinity of his blood was virtually normal $\left(P_{50}=27.0 \mathrm{~mm} \mathrm{Hg}\right)$. In contrast, on August 22, when his hematocrit was only $13.5 \%$ (the most recent transfusion had been given 15 days earlier), the oxygen affinity of his blood was markedly decreased $\left(P_{50}=29.6 \mathrm{~mm} \mathrm{Hg}\right)$ and the degree of heme-heme interaction was also higher than normal ( $n$ of 3.04 , normal $n=2.64$ ). The increases in $P_{50}$ and Hill's $n$ in the August study were both statistically significant $(P<0.01)$ compared with normal values.

\section{DISCUSSION}

Blood from hypoxemic patients with compensatory erythrocytosis differs from normal blood in having a decreased oxygen affinity. This results in an improvement in its function of oxygen delivery to tissues. For example (as illustrated in Fig. 1), with an arterial $\mathrm{Po}_{2}$ of $50 \mathrm{~mm} \mathrm{Hg}$ and a venous $\mathrm{Po}_{2}$ of $30 \mathrm{~mm} \mathrm{Hg}$, blood from normal subjects will have an arterio-venous oxygen saturation difference of $26 \%$, whereas blood from a patient with hypoxemic erythrocytosis will have an arteriovenous oxygen saturation difference of $32.5 \%$ with the same $\mathrm{Po}_{2}$ values in arterial and venous blood. The decrease in oxygen affinity would thus provide $25 \%$ more oxygen to the tissues at the same rate of blood flow and the same blood hemoglobin concentration.

We have found a similar decrease in blood oxygen affinity in patients with cardiac failure (without erythrocytosis or arterial hypoxemia) and abnormally low values for cardiac output (15).

Hemoglobin from young red cells has a lower oxygen affinity and a greater heme-heme interaction than does hemoglobin from old red cells when the red cells from one individual are separated according to in vivo age (16). For this reason a recent change in the rate of erythropoiesis would be expected to affect the affinity of whole blood for oxygen by affecting the age distribution of circulating red cells. We therefore attempted to exclude from this study patients whose recent treatment might have caused an alteration in the rate of erythropoiesis.

Distinct from the effect of therapy, changes in the age distribution of circulating red cells probably do occur in the natural histories of hypoxemic patients and may, therefore, have contributed to our findings. The red cell life span has been reported to be normal in the erythrocytosis of high altitude (17), but somewhat shortened in that resulting from the hypoxemia of chronic obstructive pulmonary disease (18). Nucleated red cells have been found in significant numbers in the peripheral blood of patients with hypoxemia secondary to pulmonary disease and of patients with congestive heart failure (19). This suggests that exceptionally young red cells are being released into the circulation. In rats, erythropoietic stimulation is associated with marked reticulocytosis and marked shortening of red cell survival (20).

On the other hand, the oxygen affinity of mature circulating red cells is subject to alteration. In our patient with aplastic anemia (P. L.), all circulating red cells had undergone erythropoiesis and maturation in the bone marrows of other. presumably normal, individuals. Before transfusion, they had 
undergone a 2-3 day period of storage at $4^{\circ} \mathrm{C}$. Storage of blood has been shown to increase its oxygen affinity (we confirmed this finding in the blood subsequently given to P. L.), but the oxygen-hemoglobin equilibrium curve returns to normal within $24 \mathrm{hr}$ after reinfusion (6). None of the red cells obtained from P. L. on 22 August 1967 could have been less than 15 days old and their mean age was probably older than those of a normal individual, an age bias which would tend to increase the oxygen affinity and decrease the heme-heme interaction of blood (16); our studies showed the opposite. This indicates that normal red cells, when transfused into an anemic person, can be modified in such a way as to decrease their oxygen affinity and to increase their heme-heme interaction. Comparison of the results of our two studies suggests that the degree of modification of oxygen affinity varied according to the severity of the anemia or to the length of time the foreign red cells were exposed to the tissues of this anemic patient. Apparently, the oxygen affinity of blood is not necessarily an intrinsic property of the red cells as they are synthesized in the bone marrow. We could not produce the change in blood oxygen affinity by producing arterial hypoxemia in normal subjects for $20 \mathrm{~min}$.

We suggest that tissue hypoxia produces some alteration within the red cell which causes a change in hemoglobin function. A diffusible metabolite of hypoxic tissue might penetrate the red cell membrane to produce such an effect. A similar decrease in the oxygen affinity of blood occurs in patients with hepatic encephalopathy which can be transferred to normal red cells by in vitro incubation with a factor (or factors) separated from plasma by column chromatography (21). On the other hand, tissue hypoxia might act by extracting a greater percentage of the oxygen from the red cells. In vitro studies have shown that deoxygenated red cells have considerably greater glycolytic activity and thus produce more lactic acid and 2,3-diphosphoglycerate (DPG) than do red cells whose hemoglobin is combined with either of the ligands, oxygen or carbon monoxide (22). Either increased acidity $(23,24)$ or an increased concentration of DPG $(25,26)$ within the red cell would be expected to decrease hemoglobin's affinity for oxygen, although we currently have no evidence that either acidity $(23,24)$ or DPG $(26,27)$ increase heme-heme interaction. DPG is readily bound to deoxygenated hemoglobin but does not bind to oxygenated hemoglobin (27). Benesch and Benesch have suggested that deoxygenation removes DPG from its free state, and thus stimulates glycolysis to replenish the stores of DPG and other organic phosphates (28), but whether tissue hypoxia is actually associated with increased red cell glycolysis is not known.

Regardless of its mechanism, a decrease in blood oxygen affinity may be a useful indicator of tissue hypoxia. We regard a decrease in blood oxygen affinity, like an increased blood hemoglobin concentration or an increased rate of blood flow, as another mechanism available to the organism for promoting the supply of oxygen to the tissues.

\section{ACKNOWLEDGMENTS}

This work was supported by Training grant HE 5499, Research grant 06042, and Cardiovascular Program Project grant HE 06336 of the National Heart Institute and the National Institute of Child Health and Human Development, Bethesda, Md., and by the Oregon Heart Association.

\section{REFERENCES}

1. Morse, M., D. E. Cassels, and M. Holder. 1950. The position of the oxygen dissociation curve of the blood in cyanotic congenital heart disease. J. Clin. Invest. 29: 1098.

2. Keys, A., F. G. Hall, and E. S. Guzman Barron. 1936. The position of the oxygen dissociation curve of human blood at high altitude. Am. J. Physiol. 115: 292.

3. Aste-Salazar, H., and A. Hurtado. 1944. The affinity of hemoglobin for oxygen at sea level and at high altitudes. Am. J. Physiol. 142: 733.

4. Hurtado, A. 1964. Animals in high altitudes: resident man. In Handbook of Physiology. IV. Adaptation to the environment. American Physiological Society, Washington, D. C.

5. Dill, D. B., A. V. Bock, C. van Caulaert, A. Fölling, L. M. Hurxthal, and L. J. Henderson. 1928. Blood as a physiochemical system. VII. The composition and respiratory exchanges of human blood during recovery from pernicious anemia. J. Biol. Chem. 78: 191.

6. Valtis, D. J., and A. C. Kennedy. 1954. Defective gas-transport function of stored red blood-cells. Lancet. 1: 119.

7. Kennedy, A. C., and D. J. Valtis. 1954. The oxygen dissociation curve in anemia of various types. J. Clin. Invest. 33: 1372.

8. Rodman, T., H. P. Close, and M. K. Purcell. 1960. The oxyhemoglobin dissociation curve in anemia. Ann. Internal Med. 52: 295. 
9. Sproule, B. J., J. H. Mitchell, and W. F. Miller. 1960. Cardiopulmonary physiological responses to heavy exercise in patients with anemia. J. Clin. Invest. 39: 378.

10. Mulhausen, R., P. Astrup, and K. Kjeldsen. 1967. Oxygen affinity of hemoglobin in patients with cardiovascular diseases, anemia, and cirrhosis of the liver. Scand. J. Clin. Lab. Invest. 19: 291.

11. Novy, M. J., M. J. Edwards, and J. Metcalfe. 1967. Hemoglobin Yakima: II. High blood oxygen affinity associated with compensatory erythrocytosis and normal hemodynamics. J. Clin. Invest. 46: 1848.

12. Hill, A. V. 1910. The possible effects of the aggregation of the molecules of hemoglobin on its dissociation curves. J. Physiol. (London). 40: 4P.

13. Edwards, M. J., and R. J. Martin. 1966. Mixing technique for the oxygen-hemoglobin equilibrium and Bohr effect. J. Appl. Physiol. 21: 1898.

14. Severinghaus, J. W. 1958. Oxyhemoglobin dissociation curve correction for temperature and $\mathrm{pH}$ variation in human blood. J. Appl. Physiol. 12: 485.

15. Metcalfe, J., D. S. Dhindsa, M. J. Edwards, and A. Mourdjinis. 1968. The oxygen dissociation curve of blood from patients with low rates of peripheral blood flow. Clin. Res. 16: 240.

16. Edwards, M. J., and D. A. Rigas. 1967. Electrolytelabile increase of oxygen affinity during in vivo aging of hemoglobin. J. Clin. Invest. 46: 1579.

17. Berlin, N. I., C. Reynafarje, and J. H. Lawrence. 1954. Red cell life span in the polycythemia of high altitude. J. Appl. Physiol. 7: 271.

18. Vanier, T., M. J. Dulfano, C. Wu, and J. F. Desforges. 1963. Emphysema, hypoxia and the polycythemic response. New Engl. J. Med. 269: 169.
19. Ward, H. P., and J. Holman. 1967. The association of nucleated red cells in the peripheral smear with hypoxemia. Ann. Internal Medicine. 67: 1190.

20. Stohlman, F., Jr. 1961. Humoral regulation of erythropoiesis. VII. Shortened survival of erythrocytes produced by erythropoietine or severe anemia. Proc. Soc. Exptl. Biol. Med. 107: 884.

21. Zimmon, D. S. 1967. Mechanism of impaired oxygen binding by hemoglobin in hepatic encephalopathy. Clin. Res. 15: 461.

22. Asakura, T., Y. Sato, S. Minakami, and H. Yoshikawa. 1966. Effect of deoxygenation of intracellular hemoglobin on red cell glycolysis. J. Biochem. 59: 524.

23. Dill, D. B. 1944. In Handbook of Respiratory Data in Aviation. Committee on Medical Research, Washington, $\mathrm{D}$. C.

24. Bartels, H., K. Betke, P. Hilpert, G. Niemeyer, and K. Riegel. 1961. Die sogenannte standard- $\mathrm{O}_{2}$-dissoziationskurve des gesunden erwachsenen menschen. Arch. Ges. Physiol. 272 : 372.

25. Benesch, R., and R. E. Benesch. 1967. The effect of organic phosphates from the human erythrocyte on the allosteric properties of hemoglobin. Biochem. Biophys. Res. Commun. 26: 162.

26. Chanutin, A., and R. R. Curnish. 1967. Effect of organic and inorganic phosphates on the oxygen equilibrium of human erythrocytes. Arch. Biochem. Biophys. 121: 96.

27. Benesch, R., R. E. Benesch, and C. I. Yu. 1968. Reciprocal binding of oxygen and diphosphoglycerate by human hemoglobin. Proc. Natl. Acad. Sci. U. S. 59: 526.

28. Benesch, R., and R. E. Benesch. 1968. Oxygenation and ion transport in red cells. Science. 160: 83 . 